Publisher homepage: www.universepg.com, ISSN: 2707-4668 (Online) \& 2707-465X (Print)

https://doi.org/10.34104/ajssls.020.076087

Asian Journal of Social Sciences and Legal Studies

Journal homepage: www.universepg.com/journal/ajssls

\title{
Familial Support as a Determinant of Women Career Development: A Qualitative Study
}

\author{
Tasnuva Yasmin ${ }^{1}$ and Chisty Asmaul Husna ${ }^{2}$ \\ ${ }^{1 \& 2}$ Development Studies Discipline, Khulna University, Khulna-9208, Bangladesh. \\ *Correspondence: snigdhaa96@gmail.com (Tasnuva Yasmin, Lecturer, Development Studies Discipline, Khulna University, \\ Khulna-9208, Bangladesh).
}

\begin{abstract}
Although women's participation in the workforce has increased remarkably in recent times but women are still lagging behind because of the traditional thinking and attitudes of their families in the context of Bangladesh. The purpose of the current study was to explore the role of the family in shaping women's career development. The study was conducted in a qualitative approach and it was exploratory in nature. The study was conducted during November-December, 2019 in Khulna division, Bangladesh. The purposive sampling procedure was used to select the 25 respondents of the study. The respondents constituted of working women from different professions. Primary data was collected through semi-structured in-depth interviews extending from 35 to 45 minutes. The collected data were analyzed using thematic analysis method and nine themes emerged from the transcripts. The emerged themes were acceptance and aspiration from family, spousal support, being a mother, grown-up children as helping hands, family and work balance, family as a social network, family as a barrier, family as a lever, and gender inequality. This research highlighted the fact that women's career practices and its development depended highly on familial roles. The family possesses the ability to affect women's career success both positively and negatively. The study revealed that women who received positive support from their families were more motivated and achieved greater success in their professional life. Family can serve both as a lever as well as a barrier in shaping a woman's career.
\end{abstract}

Keywords: Family support, Working women, Career development, Qualitative study, Levers, and Barriers.

\section{INTRODUCTION:}

One of the most significant and positive changes taking place throughout the world is that women are more concerned about their career than before and the new era has lots of career opportunities available for them. Career can be termed as a process of applying one's intellectual ability, contributing to a profession over a long time and building a well-established professional network (Redman and Wilkinson, 2001). The current study defines career from the perspective of women engagement in any kind of professional UniversePG I www.universepg.com activities. Being an entrepreneur, a service holder, a business owner, all forms of work involvement which can be measured in monetary units are being considered as career in the current research. Up to 2019, the world witnessed a 38.8 percent increase in women engagement in the global labor force (World Bank, 2020). Bangladesh is also achieving quite a progress in increasing women's participation in the workforce (Kalam and Amin, 2016). The work force participation rate for women increased from 33.5 percent in 2013 to 36.0 percent in 2017 (BBS, 2018). 
This increasing rate of women involvement in the workforce positively affects the establishment of women's rights and distinct freedoms (Boussetta, 2011). However, due to having socially defined roles and cultural practices, women still fall victim to frequent inequitable treatment at their professional arena time to time (Boussetta, 2011; Saidi, 2003). Persisting traditions in terms of gender roles and expectations continue to deeply influence their family relationships and consequently limits the total addition of women in the economic sphere (Saidi, 2003; Zerari, 2006). Families occupy a prominent place in women's life and it directly influencing women's activities in every sphere of life (Constantinidis et al., 2018). Keeping this in mind, this research aims to investigate the role of family in supporting women's career development in Bangladesh.

Family support has been regarded as a key factor in ensuring an individual's successful career development (Ferguson et al., 2012; Lapierre and Allen 2006; Pluut et al., 2018). For employed women, support at home includes spousal support, paid domestic support and voluntary domestic support from their family members (Lu et al., 2009). Ely et al. (2014) highlighted the importance of spousal support for women who have a career plan. Family holds both negative and positive impacts on women's career development. A traditional gender role which views male as main source of income and female as homemaker in families has changed over the time (Perrone et al., 2009). In present times, women are more successful in their career as there is an increasing support base from the side of their families including in laws (Constantinidis et al., 2018). Contradictorily, sometimes families also set embargos on women's working status as traditionally a woman's expected role in her family is first to be a mother and wife. Consequently, the home domain is reserved for women and the working in public for men (Benradi, 2006). Research work in this field documented a number of gender-related barriers, focusing on the lack of support from the husband and family members towards working women (Fielden and Dawe, 2004; Kirkwood, 2009). Family life and difficulties related to the balance between personal and professional responsibilities are among the main obstacles to a woman's career (Paterno et al., 2008).
Women are reported to be more affected than men by the lack of family support (Shinnar et al., 2012), and family confrontation is often mentioned as a major barricade to women's career success (Jennings and McDougald, 2007). Women-owned businesses are intensely influenced by their family member decisions and prospects (Boz and Ergeneli, 2014). Genderrelated dynamics in the familial, professional and societal environments may explain these findings (Roomi et al., 2008). Although women and men in their professions both feel some pressure in managing work and family, women professionals are often more exhausted than men when balancing between the two (Duxbury et al., 2000). Without constant family support, it is quite tough for a woman to balance between her career and taking care of her children. Some women even decide to leave their careers far in advance to have children which jeopardize their career for good (Lebrón, 2016). The situation is further worse in patriarchal societies such as Bangladesh, India and Pakistan where women not only bear a greater share of family responsibilities but also need to keep up their identity as "ideal women" (Ali, 2012; Azim, 2006). However, the number of qualitative studies performed in the context of family role in shaping a woman's career is not that great in Bangladesh. Hence, the current research venture aims to explore both the positive roles as well as the negative ones that families can play in shaping a woman's career through a qualitative approach in Bangladesh.

\section{MATERIALS AND METHODS:}

The study aimed to explore both the positive and negative roles played by a family in shaping a woman's career. Qualitative approach was selected to conduct the study so that a deep understanding about the context can be achieved. Moreover, qualitative studies have already been adopted effectively in various perception studies regarding women's career studies (Essers et al., 2010; Martinez et al., 2017). The study was exploratory in nature which was conducted during November-December, 2019. Khulna, a city resided in the southern region of Bangladesh was selected as the study area (Islam, 2020). The unit of analysis constituted of women engaged in any kind of career enterprise having a family or at least a family 
member living with her in Khulna. Purposive sampling was used to select the 25 respondents of the study (Oliver, 2010). The participants came from three different work sectors: entrepreneurship, service and informal sector.

To collect primary data of this study, in-depth interview technique was used (Hammersley, 2012). The research's in-depth interview was formed through a semi-structured way. Semi-structured interviews, the most widely used method of data collection in qualitative research (Willig, 2013), was carried out in this study so that the study is able to explore participants' perception regarding their family and career. The use of semi-structured interviews allows participants to express themselves freely on predefined themes, in order to increase the richness and diversity of responses (Creswell, 2017). The duration of the interviews was 35 to 45 minutes. Each and every interview was recorded through an audio recording device and the interviews were fully transcribed in the next step. Transcribing data is widely accepted as a key part of qualitative analysis as profound meaning and insights about the collected data emerge from this process (Shalin, 2014). Afterwards, the data collected through individual interviews were subject to a thematic content analysis (Maguire and Delahunt, 2017). Under thematic analysis, the transcript was studied repeatedly and different patterns were identified. These patterns were then organized into a number of themes and sub-themes, allowing for an indepth understanding of the personal perceptions and representations of the respondents.

At the very beginning of the interview procedure, each and every respondent was asked for their consent and all of them participated voluntarily for this research activity. They were assured that their identity will be kept confidential and their responses will only be used for the sole purpose of academic research. To keep the identity of the respondents confidential, each respondent was provided with a code number and they had been termed as Respondent 1, 2, 3,...25 throughout the study.

\section{RESULTS:}

The socio-economic condition of the respondents can positively or negatively affect their familial role in determining their career. It will be further reflected through the thematic analysis of their responses in the next phase.

Table 1: Socio-Economic Information of the Respondents

\begin{tabular}{|c|c|c|c|c|c|}
\hline $\begin{array}{c}\text { Respondent } \\
\text { No. }\end{array}$ & $\begin{array}{c}\text { Level of } \\
\text { Education }\end{array}$ & $\begin{array}{c}\text { Marital } \\
\text { status }\end{array}$ & $\begin{array}{c}\text { Number of } \\
\text { children }\end{array}$ & $\begin{array}{c}\text { Family income } \\
\text { levels }\end{array}$ & Profession \\
\hline $\mathbf{1}$ & Masters & Married & 2 & Satisfying & Government Official \\
\hline $\mathbf{2}$ & Masters & Married & 2 & Satisfying & School Teacher \\
\hline $\mathbf{3}$ & Masters & Married & 2 & Satisfying & Entrepreneur \\
\hline $\mathbf{4}$ & Masters & Married & 2 & Satisfying & Accountant \\
\hline $\mathbf{5}$ & SSC & Widow & 1 & Satisfying & MLSS \\
\hline $\mathbf{6}$ & Graduate & Married & 2 & Not Satisfying & Business-Women \\
\hline $\mathbf{7}$ & Graduate & Married & 2 & Satisfying & Service Holder \\
\hline $\mathbf{8}$ & Masters & Married & 2 & Satisfying & Banker \\
\hline $\mathbf{9}$ & Graduate & Divorced & 1 & Not Satisfying & Instructor \\
\hline $\mathbf{1 0}$ & HSC & Married & 1 & Not Satisfying & Computer Operator \\
\hline $\mathbf{1 1}$ & Masters & Married & 1 & Satisfying & Assistant Officer \\
\hline $\mathbf{1 2}$ & Graduate & Unmarried & 0 & Not Satisfying & Entrepreneur \\
\hline $\mathbf{1 3}$ & Graduate & Married & 0 & Not Satisfying & Business-Women \\
\hline $\mathbf{1 4}$ & SSC & Married & 1 & Not Satisfying & Sales Women \\
\hline $\mathbf{1 5}$ & Masters & Married & 2 & Satisfying & Beauty Expert \\
\hline $\mathbf{1 6}$ & Graduate & Separated & 1 & Satisfying & Entrepreneur \\
\hline
\end{tabular}




\begin{tabular}{|c|c|c|c|c|c|}
\hline $\mathbf{1 7}$ & Graduate & Married & 2 & Satisfying & Entrepreneur \\
\hline $\mathbf{1 8}$ & Masters & Married & 2 & Not Satisfying & Business-Women \\
\hline $\mathbf{1 9}$ & Graduate & Married & 1 & Satisfying & Receptionist \\
\hline $\mathbf{2 0}$ & HSC & Married & 1 & Satisfying & Clark \\
\hline $\mathbf{2 1}$ & Graduate & Married & 2 & Not Satisfying & Service Holder \\
\hline $\mathbf{2 2}$ & Masters & Married & 1 & Not Satisfying & Entrepreneur \\
\hline $\mathbf{2 3}$ & Graduate & Unmarried & 0 & Satisfying & Store-Keeper \\
\hline $\mathbf{2 4}$ & Graduate & Unmarried & 0 & Satisfying & Entrepreneur \\
\hline $\mathbf{2 5}$ & SSC & Married & 2 & Satisfying & Housekeeper \\
\hline
\end{tabular}

From the thematic analysis of the collected data, nine different themes emerged in the context of understanding the role of family in shaping a woman's career. Themes that emerged were acceptance and aspiration from family, spousal support, being a mother, grown up children as helping hands, family and work balance, family as a social network, family as a barrier, family as a lever and gender inequality.

Acceptance and Aspiration from Family - Majority of the respondents stated that acknowledgement about their career from family mattered the most to them. In many cases, family members of the respondents were quite positive about their profession and supported them in successfully managing their career. Moreover, some of the respondents received monetary help from their families. Capital provision and other material as well as mental support from families helped to reduce the impediment in the way of their successful career.

People of my society said many bad things about me and my job. But I did not falter as my family was there for me. They were positive about my career and supported me to work as a beautician (Respondent-15).

Some respondents took a break from their work but their family inspired them to rejoin the work force. The mental aspiration was as much important for the respondents as any other material support. Family members also acted as role models for a number of respondents who inspired them in choosing their career. But acceptance of career by one's family was not always the case. The scenario was especially difficult for married women with children belonging to middleclass families who chose to build their career with little or no work experience. Their family members were not pleased about them working outside of home as it was contradictory with their traditional UniversePG I www.universepg.com thinking. Moreover, it was hard for these women to balance between their family and work. Interestingly, women from families who had lower income level did not care much about their family's perception as working was not a choice for them. They did it just for the sake of feeding their families.

Spousal Support - The respondents' career developpment has repeatedly indicated towards the importance of positive reinforcement from their significant others. In most of the cases, they received support from their husbands in crisis situations. The supporting spouses also helped the respondents in major decision-making process concerning their career.

No one was in my favor when I first started my job. It made me feel helpless. Then my husband provided me with confidence. He was there to cheer me up and inspired me to be positive regarding my career (Respondent-21).

The middle-aged women mostly enjoyed a neutral and silent response from their spouses regarding their career planning. But sometimes, they expected additional support from their better halves which gave rise to domestic conflicts between the partners.

I was born into a well-educated family and was married into a well-cultured as well-educated family also. Despite the fact, I was not allowed to run a business as my husband did not like that. He preferred me to be playing only the role of his wife and a mother to his son (Respondent$3)$.

A number of respondents belonging from low-income families met with domestic violence by their husbands for working in night shifts. Quite a few highly educated husbands also bore negative perception regarding their wife's profession and would be more 
comfortable with their wives being limited to only maintaining household chores. In few cases, respondents got divorce from their husband or lived separately because they were career oriented. The respondents believed that spousal approval and support play a great role to create further acceptance in the society regarding women maintaining a career.

Being a mother - Most of the respondents of the current study were married and had children. Some received familial support regarding taking care of their babies. The entrepreneur women faced greater difficulties when they had children as maintaining business and raring children simultaneously were not easy task for them. Respondents' parents as well as inlaws helped them in babysitting issues when they were away from home for work purposes. For respondents in service sector also, it was quite tough to choose between job and having a family. By the assistance of their family they were able to maintain both and even succeed in a lot of incidences.

I was still unmarried when I started my career. I got married after 5 years of engagement in my career and had my son at the age of 29. Maintaining both my household as well as career was possible only because the support provided by both my parents as well as my inlaws in taking care of my son (Respondent-4).

Few respondents mentioned that they witnessed some obstacles during their pregnancy and were tortured due to their engagement in their profession. They also faced great difficulties in taking care of their children as they were devoid of any familial support.

Grown up Children as Helping Hands - Most of the married respondents had at least one grownup son or daughter and the children helped their mother by taking care of their younger siblings when respondents were away from home. Majority of the respondents agreed that their elder children were a big support for them and shared responsibilities of the household in their absence.

My eldest daughter helps me with the household chores and also in taking care of her younger siblings. As she does not go to school, she is the one who takes my responsibility up in the house when I am at work (Respondent-5).

UniversePG I www.universepg.com
The respondents employed in the informal sector had long and laborious working hours. The faced extreme difficulties in their workplace and were exhausted when coming back home from work. They could not perform their daily household chores in this situation and their grown up understood the situation perfectly and shared household responsibilities with them.

Family and Work Balance - To maintain both family and career was the toughest responsibility for the respondents during their career establishment. Half of the respondents agreed upon the fact that they almost lost their mind to cope up with that situation. Getting flexibility from families, made it easy for them to keep up balance between family and work.

I don't need to work at all at home as my mother helps me to sort out my familial tasks. Because of her support, I can manage to maintain a balance between my family and my job (Respondent-19).

Few of the respondents mentioned that conflict aroused when they failed to attain the balance between their work and family. The guiding hands of the elder members in family served as the resolving mechanism to these disputes. Mother or their mother-in-law in the family worked as the main powerhouse for these women and provided them with crucial advice regarding maintain the responsibility in both home and work.

Family as a Social Network/Capital - Family was the first business network for the businesswomen among the respondents. The respondents generally preferred informal networks rather than formal ones. The social network of the family played a key role for the entrepreneurs especially when they started their businesses. These women mentioned that they were able to make their companies run in the early stage only because of the customers sent by family relatives.

There are many companies which manufacture the same products as us. So, competition is rather high in this sector. Since our enterprise is not based in a commercial area, we ask our family, acquaintances and neighbors to spread some good words about us (Respondent-12). 
The relationships created through the contacts provided by their family circle also contributed to the development of their activity which was largely based on their family social capital. Similarly, for serviceholder women, the family network contributed a lot to their career success.

When I started working at a bank, I was not well-known and I was struggling to make my day cost-effective. Sometimes, no client came to me to open an account the entire day. But thanks to my relatives, who recommended our bank to their acquaintances and I began to receive more and more clients (Respondent-8).

The participation and commitment of their family in their professional activities was not only useful when starting their career but also for daily occupational management and long-term development. It gave them access to numerous economic opportunities also. Because of their family social capital, these women were able to develop such professional relationships which would have been difficult to achieve otherwise.

Family as a Barrier - The study highlighted the diversity of roles that family can play in women's career. Indeed, family can act not only as a lever but also as a barrier for their career progression in terms of financial, professional, and moral support. Major obstacles which were identified included negative opinions and confrontation towards women's career from their close relatives, particularly their husband. Another difficulty faced by women was related to family and work life balance. Majority of the respondents stated that the unequal distribution of household and family tasks between men and women led women towards sacrificing career-related dimensions.

In this male dominated society, we women are way too helpless. I faced many complications regarding my career. Years back, I was forced to quit my job because was not capable to uphold my familial roles. It was very stressful for me (Respondent-11).

The family-related barriers on women's career were mostly based on the patriarchal socio-cultural perception prevalent in our country. In some cases, the

UniversePG I www.universepg.com married respondents stated that their income was considered secondary due to the higher income of their spouses. This humiliating treatment de-motivated many of them to leave their career. To fulfill familial responsibility, respondents often had to sacrifice their career or take days off from work which hampered their work life. They expressed that if their family was there for them and share their responsibilities rather than forcing them to quit, they could have achieved better career development.

Family as a Lever - It was given that all the respondents wanted their family to be working as a lever behind the success of their career. Despite the hindering prospects of their family, they still thought if their family was not there from them, they could not have developed their career. Out of the 25 respondents, 12 respondents implied that family was last resort for them in their need. it inspired them to concentrate more on their career. Some of the respondents said that they were going to leave their business because of suffering from continuous loss but their family helped them to regain their position.

I went through a huge loss in my business and all my investment was gone. I was going to be bankrupt when my brother showed up as a savior. He repaid my loans and gave me confidence to restart my business as anew (Respondent-16).

In many cases, family members were the critics of the respondents' work which helped them in further improving their performance. Family worked as the motivator, guide, instructor and critic towards the respondents for their career success.

Once I received a demotion from my position in my job. It was very sudden and I felt frustrated as I had no clues about what I have done wrong. My husband gave some thought about the incident and suggested me to improve my computer skills. This new learned skill further improved my performance at my work and after a few months I got promoted again (Respondent-7).

In terms of married respondents, sometimes their inlaws and husbands were more supportive as well encouraging than their own parents. Many in-laws of 
the respondents provided them with confidence and invested into their daughter-in-laws career where their parents were not willing to do so.

Gender Inequality - Inequality between men and women was one of the most shared statements among the respondents. Male members were always preferred as the bread earners of the family, not the females. Few respondents shared that it felt unfair to them that their brothers and husbands were allowed to outside for business purposes at any given hour but women were restricted to do so.

I need to go to different cities for my business purposes. Sometime, I had to return home late in the night and faced unpleasant confrontations from my family. On different occasions, I was told that I was not like my brother and was not allowed to return home whenever I wished to do so (Respondent-9).

Despite belonging in a modern family, mostly the fathers of the respondents were reluctant to allow their daughter to start a career. Their perception was that as the family possessed plenty of wealth, there was no need for the women to work outside of home. Men could go through any means for the prosperity of their career but when it came to the women, in most cases respondents were victim of gender inequality within their family.

My mother-in-law once told me that I did not need to work as my husband earned enough for the family. I was told to stay home and fulfill my traditional roles as wife and as a mother. it was my responsibility as a woman (Respondent23).

Majority of the married respondents were mistreated concerning their career. Respondents also faced discrimination regarding their salary. Their salary was always considered to be secondary to their husbands and most of their salary was spent in domestic purposes where they had no say about it.

\section{DISCUSSION:}

The study analyzed the respondents' distinguished experiences to interconnect dynamic forces in terms of gender and social class. The first theme of the study was acceptance and aspiration from family. Along with people's individual expectations, support within the family, social environment and prevailing trends in economic and social policy, all of these things influenced the process of women's entry into the working world (Klammer, 2008). The society considered women's role as a sole provider only when their husbands could not provide adequate financial support to the family or were completely jobless. But this perception is gradually changing and family members are accepting women's career persuasion in a good way (Rattani, 2012). The current study agreed with this perception but some participants expressed their concern that Bangladeshi culture as well as individual's family are still lagging a little bit behind to accept women's engagement in workforce completely. The next phase was aspiration which originally came from home. Present study showed that respondents received most of their aspirations from their parents as well as relatives. Family was key to women's inspiration to remain engaged in workforce, regardless of the hurdles they encountered along the way. Earning a promotion or making one's family proud worked as strong motivators behind investing in career (Vaccaro and Lovell, 2010). The current study mentioned that family reopened career opportunities for women which they missed previously. Existing literatures also agreed with this argument stating that if women's family is supportive regarding their career, women could retain their position in their respective work field (Buse et al., 2013).

The second the me was spousal support. A spouse supports a partner's career by discussing and offering new points of view to assist decision making and planning regarding one's career. A supportive spouse adopts a flexible role in relation to the other partner's career i.e. he accommodates the career demands of his partner to the best of his ability (Selmer et al., 2011). In most of the cases of the current study, respondents received spousal flexibility but complications also raised when women faced negative insights and opposition towards their career from their close relatives, mainly from their husband. The spousal care is needed for every woman to shine in her career. The role of the spouse has been viewed as a bridge between work and family reconciliation. However, a detailed 
view of the role from a career perspective has received less attention (Valimaki et al., 2009).

The third theme talks about balancing between motherhood and career. In the current study, many women were successful in building their career with the support of family in raring their children. Literature also showed similar results stating that women relied on their parents, spouse and in-laws to take care of their children when setting up their career (Duberley and Carrigan, 2013). Women often faced contradictory social expectations with regard to career success and motherhood. Many respondents decided to leave their job for the sake of motherhood. If a woman's family does not assist her during her motherhood or until her children are grown up, rearing children is one of the toughest responsibilities for a lone woman which can adversely affect their career (Cheung \& Halpern, 2010).

The next the me was "Grown up Children as Helping Hands". Existing literature showed that in order to maintain a balance between family and work life, working women relied heavily on their elder children, especially their eldest daughters to take care of a large part of the household responsibilities (Constantinidis et al., 2018). The present study also showed a similar result in this regard. The fifth theme was "Family and work balance". This study showed that the imbalanced distribution of domestic and family tasks between men and women was still prevalent leading women towards sacrificing their career development. Many ample streams of literature identified the difficulties faced by working women in terms of family and work life balance as disadvantageous to their career success (Fairlie and Robb, 2009; Hundley, 2001; Rouse and Kitching, 2006). Work and family may both wield substantial demands on both men and women in terms of creating role conflicts (Greenhaus and Beutell, 1985). Study findings stated that sometimes respondents failed to maintain that dual role in their career and family responsibilities. The sixth theme of the study was "Family as a social network". Family acted as a social network in getting recognition in their respective work sector for women in the current study. Most of the entrepreneur respondents enjoyed this positive familial social status as their resources in their business. Literature also stated that if women pursue UniversePG I www.universepg.com their careers within open and diverse networks, they can reduce their disadvantaged position and the risk of dropping out of the business to a level (Lutter, 2015). Family status helps women to become more relevant in society to get their own identity beyond their family surname. This family status serves as social capital or network. Specifically, it helps in acquiring new jobs, establishing future collaborations, and creating teams (Godechot \& Mariot, 2004). The next two themes of the current study included a discussion on how family can work as a lever or barrier for a woman. Though, specific literatures regarding those two could not be found, all of the literatures somehow relate with the particular discussion.

The last theme was "Gender Inequality". Each and every respondent of the current study was a victim of gender inequality within their family regarding their career obligation. Family put more emphasis on male's career development than women. Respondents were not allowed to stay late in night for their professional purposes like men. Family usually considered their profession as a hobby. Contextual studies in developing countries also explored the family-related barriers on women's career in light of the male sociocultural environment of these countries, especially the traditional gender division of roles and responsibilities (Ghouse et al., 2017; Mehtap et al., 2017). Career development of the male members of the family often take priority over women. This often means that when location and relocation decisions are made, women's careers are considered to be subordinated to men's (Stone and Lovejoy 2004). Numerous studies have documented this phenomenon across academic fields (Primack and O'Leary 1993; Harper et al., 2001).

\section{CONCLUSION:}

The current study was conducted with a goal to explore the role of family in shaping women's career development. The study identified nine themes to explain the familial role in this context. However, the study revealed that women's career was still perceived as secondary in the household but the scenario was changing as social accepting of women's professional activities was increasing gradually. The present research revealed strong involvement of spouse in all operational decisions relating to the women's career 
development. The women generally saw this involvement as a positive aspect but it also made them vulnerable as they were depending so much on their spouses concerning their career's important decisions. Women also received huge level of domestic support from their parents and in-laws in maintaining a balance between job and work responsibilities. The grown-up children and other family members of the respondents helped them in taking care of their younger offspring. They also received moral as well as financial support and the privilege of having a familial network when starting up their business. Now, focus is needed to be converted towards the negative aspects of the familial role regarding women's career. Women fell victim of various gender-based inequalities. Their career was always considered to be inferior comparatively to their male counterparts. A number of restrictions were imposed upon the women which were not applicable for the men. Therefore, the study results basically revealed that the familial role could affect the career of a woman both positively as well as negatively. This dual role of the family in shaping women's career further emphasized on the fact regarding how important family is for a successful development of women's career. It is expected that the gradual shift from the traditional patriarchal society prevalent in Bangladesh will further improve the familial role to be more positive in shaping women's career. Further studies regarding this context are highly recommended and expected to add more values to the concept.

\section{ACKNOWLEDGEMENT:}

The authors would like to express their gratitude towards all the participants of the study who granted their valuable time for the purpose of the research despite their hectic schedule. Authors are also thankful to all of the faculties of Development Studies Discipline, Khulna University for providing guidelines throughout the research work. At last but not the least, family members of both authors are needed to be mentioned as it was quite impossible to complete the current study without their constant mental support.

\section{CONFLICT OF INTERESTS:}

It is being declared by the authors that there is no conflict of interest regarding the authorship or publication of this original research article.

UniversePG I www.universepg.com

\section{REFERENCES:}

1. Ali, R. (2012). Changing Expectations of Gender Roles in Bangladesh: The Case of Female Field Staff of BRAC. Research Monograph Series, 52. Chicago.

2. Azim, F. (2006). The new 21st century woman. In Scoping Workshop of the South Asia Hub of the Pathways of Women's Empowerment Research Consortium, Dhaka (pp. 18-21).

3. Bangladesh Bureau of Statistics (BBS), (2018). Report on labor force survey (LFS) 2016-17.

4. Benradi, M. (2006). Prospective Maroc 2030: dynamiquesociale et évolution des statuts des femmes au Maroc. Rabat, Maroc, HautCommissariat au Plan.

5. Boussetta, M. (2011), “Entreprenariat féminin au Maroc: environnement et contribution au développement économique et social", Research Report No. 10-11, Investment Climate and Business Environment Research Fund, Dakar.

6. Boz, A., \& Ergeneli, A. (2014). Women entrepreneurs' personality characteristics and parents' parenting style profile in Turkey. Procedia-social and behavioral sciences, 109, 92-97.

https://doi.org/10.1016/j.sbspro.2013.12.425

7. Buse, K., Bilimoria, D., \& Perelli, S. (2013). Why they stay: Women persisting in US engineering careers. Career Development International, 18(2), 139-154.

https://doi.org/10.1108/CDI-11-2012-0108

8. Cheung, F. M., \& Halpern, D. F. (2010). Women at the top: Powerful leaders define success as work+ family in a culture of gender. American psychologist, 65(3), 182. https://psycnet.apa.org/doi/10.1037/a0017309

9. Constantinidis, C., Lebègue, T., El Abboubi, M., \& Salman, N. (2018). How families shape women's entrepreneurial success in Morocco: an intersectional study. International J. of Entrepreneurial Behavior \& Research, 25(8): 1786-1808.

https://doi.org/10.1108/IJEBR-12-2017-0501 
10. Creswell, J. W., \& Creswell, J. D. (2017). Research design: Qualitative, quantitative, and mixed methods approaches. Sage publiccations.

11. Duberley, J., \& Carrigan, M. (2013). The career identities of 'mumpreneurs': Women's experiences of combining enterprise and motherhood. International small business journal, 31(6), 629-651. https://doi.org/10.1177\%2F0266242611435182

12. Duxbury, L. E., Dyke, L. S., \& Lam, N. (2000). Managing high technology employees. Canadian HR reporter.

13. Martinez Dy, A., Marlow, S., \& Martin, L. (2017). A Web of opportunity or the same old story? Women digital entrepreneurs and intersectionality theory. Human Relations, 70(3), 286-311. https://doi.org/10.1177\%2F0018726716650730

14. Ely, R. J., Stone, P., \& Ammerman, C. (2014). Rethink what you "know" about highachieving women. Harvard Business Review, 92(12), 100-109.

15. Essers, C., Benschop, Y., \& Doorewaard, H. (2010). Female ethnicity: Understanding Muslim immigrant businesswomen in the Netherlands. Gender, Work \& Organization, 17(3), 320-339. https://doi.org/10.1111/j.14680432.2008.00425.x

16. Fairlie, R. W., \& Robb, A. M. (2009). Gender differences in business performance: evidence from the Characteristics of Business Owners survey. Small Business Economics, 33(4), 375.

17. Ferguson, M., Carlson, D., Zivnuska, S., \& Whitten, D. (2012). Support at work and home: The path to satisfaction through balance. J. of Vocational Behavior, 80(2), 299307. https://doi.org/10.1016/j.jvb.2012.01.001

18. Fielden, S. L., \& Dawe, A. (2004). Entrepreneurship and social inclusion. Women in Management Review. https://doi.org/10.1108/09649420410529843

19. Ghouse, S., Mc Elwee, G., Meaton, J., \& Durrah, O. (2017). Barriers to rural women entrepreneurs in Oman. Intern. J. of Entrepren. Behav. \& Res., 23(6): 998-1016 https://doi.org/10.1108/IJEBR-02-2017-0070
20. Godechot, O., \& Mariot, N. (2004). Les deux formes du capital social. Revue française de sociologie, 45(2), 243-282.

21. Greenhaus, J. H., \& Beutell, N. J. (1985). Sources of conflict between work and family roles. Academy of management review, 10(1), 76-88. https://doi.org/10.5465/amr.1985.4277352

22. Hammersley, M. (2012). What is qualitative research? A\&C Black.

23. Harper, E. P., Baldwin, R. G., Gansneder, B. G., \& Chronister, J. L. (2001). Full-time women faculty off the tenure track: Profile and practice. The Review of Higher Education, 24(3), 237-257. https://doi.org/10.1353/rhe.2001.0003

24. Hundley, G. (2001). Why women earn less than men in self-employment. Journal of labor research, 22(4), 817-829.

25. Islam MJ. (2020). Factors influencing family size: a critical study on Khulna district of Bangladesh, Br. J. Arts Humanit., 2(4), 73-81. https://doi.org/10.34104/bjah.020073081

26. Jennings, J. E., \& McDougald, M. S. (2007). Work-family interface experiences and coping strategies: Implications for entrepreneurship research and practice. Academy of management review, 32(3), 747-760. https://doi.org/10.5465/amr.2007.25275510

27. Kalam, I., \& Amin, M. (2016). Trends of women's participation in economic activity of Bangladesh: Status and Disparity. European Scientific Journal, 12(35), 50-58. http://dx.doi.org/10.19044/esj.2016.v12n35p50

28. Klammer, Ute. (2008). Independent and derived livelihood of women in Germany empirical findings, in: Documentation of the meeting Ownership, private and public Solidarity - role models in family and social law in European comparison. Host Country Paper Report.

29. Kirkwood, J. (2009). Spousal roles on motivations for entrepreneurship: A qualitative study in New Zealand. J. of Family and Economic Issues, 30(4), 372.

30. Lapierre, L. M., \& Allen, T. D. (2006). Worksupportive family, family-supportive super- 
vision, use of organizational benefits, and problem-focused coping: implications for work-family conflict and employee wellbeing. J. of occupational health psychology, 11(2), 169.

https://psycnet.apa.org/doi/10.1037/1076-8998. $\underline{11.2 .169}$

31. Lebrón, M. J. (2016). Lean In: Women, Work, and the Will to Lead.

https://doi.org/10.5465/amle.2015.0373

32. Lu, J. F., Siu, O. L., Spector, P. E., \& Shi, K. (2009). Antecedents and outcomes of a fourfold taxonomy of work-family balance in Chinese employed parents. J. of occupational health psychology, 14(2), 182.

https://psycnet.apa.org/doi/10.1037/a0014115

33. Lutter, M. (2015). Do women suffer from network closure? The moderating effect of social capital on gender inequality in a projectbased labor market, 1929 to 2010. American Sociological Review, 80(2), 329-358. https://doi.org/10.1177\%2F0003122414568788

34. Maguire, M., and Delahunt, B. (2017). Doing a thematic analysis: A practical, step-by-step guide for learning and teaching scholars. AISHE-J: The All Ireland Journal of Teaching and Learning in Higher Education, 9(3).

35. Mehtap, S., Pellegrini, M. M., Caputo, A., \& Welsh, D. H. (2017). Entrepreneurial intentions of young women in the Arab world. International J. of Entrepreneurial Behavior \& Research, 23(6): 880-902.

https://doi.org/10.1108/IJEBR-07-2017-0214

36. Oliver, P. (2010). The student's guide to research ethics, $2^{\text {nd }}$ edition. Berkshire: Open University Press.

37. Paterno, A., Gabrielli, G., \& D'Addato, A. (2008). Travail des femmes, caractéristiques familiales et sociales: le cas du Maroc. Cahiers québécois de démographie, 37(2), 263-289. https://doi.org/10.7202/038133ar

38. Perrone, K. M., Wright, S. L., \& Jackson, Z. V. (2009). Traditional and nontraditional gender roles and work Family interface for men and women. J. of Career Development, 36(1), 8-24.

https://doi.org/10.1177\%2F0894845308327736
39. Pluut, H., Ilies, R., Curşeu, P. L., \& Liu, Y. (2018). Social support at work and at home: Dual-buffering effects in the work-family conflict process. Organizational Behavior and Human Decision Processes, 146, 1-13. https://doi.org/10.1016/j.obhdp.2018.02.001

40. Rattani, S. (2012). Working and Nonworking Women's descriptions and experiences of their roles in Society. International J. of Humanities and Social Science, 2(19), 230.

41. Redman, T., \& Wilkinson, A. (2001). In search of human resource management. Contemporary human resource management, 3-23.Chicago.

42. Roomi, M. A., \& Parrott, G. (2008). Barriers to development and progression of women entrepreneurs in Pakistan. The Journal of Entrepreneurship, 17(1), 59-72.

https://doi.org/10.1177\%2F097135570701700105

43. Rouse, J., \& Kitching, J. (2006). Do enterprise support programmes leave women holding the baby? Environment and Planning C: Government and Policy, 24(1), 5-19. https://doi.org/10.1068\%2Fc0528

44. Saidi, S. (2003), "Genre et économie: la participation des femmes à la vie économique", in AlamiM'Chichi, H., Benradi, M., Chaker, A., Mouaqit, M., Saadi, M.S. and Yaakoubd, A.I. (Eds), Féminin-Masculin: La Marche versl'Egalité au Maroc 1993-2003, Friedrich-Ebert-Stiftung, FES Maroc, Rabat, pp. 149-192.

45. Selmer, J., Suutari, V., Mäkelä, L., \&Känsälä, M. (2011). The roles of expatriates' spouses among dual career couples. Cross Cultural Management: An Intern. J., 18(2): 185-197. https://doi.org/10.1108/13527601111126012

46. Shalin, H J. (2014). Enhancing qualitative and mixed methods research with technology. IGI Global: Hershey PA.

47. Shinnar, R. S., Giacomin, O., \& Janssen, F. (2012). Entrepreneurial perceptions and intentions: The role of gender and culture. Entrepreneurship Theory and practice, 36(3), 465-493.

https://doi.org/10.1111\%2Fj.1540-6520.2012. 00509.x 
48. Stone, P., \& Lovejoy, M. (2004). Fast-track women and the "choice" to stay home. The Annals of the American Academy of Political and Social Science, 596(1), 62-83. https://doi.org/10.1177\%2F0002716204268552

49. The World Bank; Labor Force, female (\% of total labor force) (2020), The World Bank, Retrieved from:

https://data.worldbank.org/indicator/SL.TLF.TO TL.FE.ZS

50. Vaccaro, A., \& Lovell, C. D. (2010). Inspiration from home: Understanding family as key to adult women's self-investment. Adult Education Quarterly, 60(2), 161-176. https://doi.org/10.1177\%2F0741713609336111
51. Valimaki, S., Lämsä, A. M., \& Hiillos, M. (2009). The spouse of the female manager: role and influence on the woman's career. Gender in Management: An International Journal, 24(8), 596-614. https://doi.org/10.1108/17542410911004867

52. Willig, C. (2013). Introducing qualitative research in Psychology. Berkshire: McGrawHill.

53. Zerari, H. (2006). Femmes du Maroc entre hier et aujourd'hui: quells changements. Recher chesinternationales, 3(77), 65-80.

https://www.recherches-internationales.fr/RI77/ RI77-hayat-zerari.pdf

Citation: Yasmin T., and Husna CA. (2020). Familial support as a determinant of women career development: a qualitative study, Asian J. Soc. Sci. Leg. Stud., 2(4), 76-87. https://doi.org/10.34104/ajssls.020.076087 @) () 